\title{
Мультидисциплінарний підхід до реабілітації пацієнтів 3 порушеннями рухових функцій внаслідок перенесеного інсульту
}

\author{
Ковальова С. В., Дондарєва І. С., Пономарьова Г. В., Данильчук А. В., Галенко М. О. \\ Український науково-дослідний інститут протезування, протезобудування та відновлення \\ працездатності, м. Харків, Україна
}

\begin{abstract}
Актуальність. На сьогодні проблема реабілітації пацієнтів після перенесеного інсульту в Україні, як і в усьому світі, дуже актуальна. Він $є$ однією з основних причин інвалідизації населення.
\end{abstract}

Мета дослідження: підвищення ефективності організації відновлювального лікування пацієнтів після перенесеного інсульту шляхом застосування організаційної моделі реабілітаційного процесу "мультидисциплінарна команда”.

Матеріали та методи. Було вивчено та інтегровано в практику застосування моделі організації реабілітації "Мультидисциплінарна команда". Визначено склад команди та етапи її діяльності.

Результати дослідження та їх обговорення. До складу мультидисциплінарної команди увійшли наступні фахівці: невропатолог, терапевт, фізичний терапевт, психолог, ортопед-травматолог, ортезист. На початковому етапі проводилися визначення функціональних можливостей пацієнтів шляхом проведення тестування та міографічного дослідження. Після отримання та опрацювання даних для визначення мети реабілітаційного курсу проводились співбесіди 3 пацієнтами та обговорювалися шляхи досягнення мети на засіданнях мультидисциплінарної команди. На даному етапі також відбувалось формування індивідуальної програми реабіліта- ції, яка містить у собі план дій кожного фахівця, що входить до мультидисциплінарної команди, таким чином, щоб одночасно вирішувалися комплексні завдання, проводилися заходи відновного лікування, що не виключали одне одного та мали взаємно посилюючий вплив. Далі визначались терміни проміжного контролю ефективності реабілітаційних дій задля подальшого коректування реабілітаційної програми. На наступному етапі проводилися програми реабілітації та проміжний контроль шляхом здійснення повторного тестування й інших методів дослідження. Також, враховуючи функціональні можливості пацієнта, визначались показання щодо призначення ортезних систем. На заключному етапі курсу відновлювального лікування проводилась оцінка ефективності реабілітаційних дій в цілому і кожного окремого фахівця, що входив до складу команди, та оцінка досягнення мети реабілітаційного курсу.

Висновки. Впровадження моделі організації реабілітаційного процесу «Мультидисциплінарна команда» дає змогу побудувати і виконати комплексну реабілітацію пацієнтів після перенесеного інсульту: якомога раніше відновити, досягти компенсації порушених функцій, зменшити ускладнення та ступінь інвалідизації.

Ключові слова: інсульт, мультидисциплінарна команда, програма реабілітації. 